\title{
The influence of the North Atlantic Oscillation and EI Niño-Southern Oscillation on mean and extreme values of column ozone over the United States
}

\author{
I. Petropavlovskikh ${ }^{1}$, R. Evans $^{2}$, G. McConville ${ }^{1}$, G. L. Manney ${ }^{3,4}$, and H. E. Rieder ${ }^{5,6}$ \\ ${ }^{1}$ Cooperative Institute for Research in Environmental Sciences, University of Colorado, Boulder, CO 80309, USA \\ ${ }^{2}$ NOAA Earth System Research Laboratory, Boulder, CO 80305, USA \\ ${ }^{3}$ NorthWest Research Associates, Socorro, NM 87801, USA \\ ${ }^{4}$ Department of Physics, New Mexico Institute of Mining and Technology, Socorro, NM 87801, USA \\ ${ }^{5}$ Wegener Center for Climate and Global Change and IGAM/Institute of Physics, University of Graz, 8010 Graz, Austria \\ ${ }^{6}$ Lamont-Doherty Earth Observatory of Columbia University, Palisades, NY 10964, USA
}

Correspondence to: I. Petropavlovskikh (irina.petro@ noaa.gov)

Received: 22 May 2014 - Published in Atmos. Chem. Phys. Discuss.: 15 August 2014

Revised: 11 December 2014 - Accepted: 7 January 2015 - Published: 13 February 2015

\begin{abstract}
Continuous measurements of total ozone (by Dobson spectrophotometers) across the contiguous United States began in the early 1960s. Here, we analyze temporal and spatial variability and trends in total ozone from the five US sites with long-term records. While similar long-term ozone changes are detected at all five sites, we find differences in the patterns of ozone variability on shorter timescales. In addition to standard evaluation techniques, STL-decomposition methods (Seasonal Trend decomposition of time series based on LOESS (LOcally wEighted Scatterplot Smoothing)) are used to address temporal variability and "fingerprints" of dynamical features in the Dobson data. Methods from statistical extreme value theory (EVT) are used to characterize days with high and low total ozone (termed EHOs and ELOs, respectively) at each station and to analyze temporal changes in the frequency of ozone extremes and their relationship to dynamical features such as the North Atlantic Oscillation (NAO) and El Niño-Southern Oscillation. A comparison of the fingerprints detected in the frequency distribution of the extremes with those for standard metrics (i.e., the mean) shows that more fingerprints are found for the extremes, particularly for the positive phase of the NAO, at all five US monitoring sites. Results from the STL decomposition support the findings of the EVT analysis. Finally, we analyze the relative influence of low- and high-ozone events on seasonal mean column ozone at each station. The results show that the influence of ELOs and EHOs on seasonal mean column
\end{abstract}

ozone can be as much as $\pm 5 \%$, about as large as the overall long-term decadal ozone trends.

\section{Introduction}

Long-term monitoring of ozone is critical because it is instrumental in controlling the levels of ultraviolet radiation reaching the planet's surface and thus plays an important role in the existence of life on Earth (e.g., Tourpali et al., 2009; Bais et al., 2011; McKenzie et al., 2011). The 25th anniversary of the Montreal Protocol (signed in 1987) marked an important milestone in the phasing-out of man-made chemicals such as chlorofluorocarbons (CFCs), commonly referred to as ozone-depleting substances (ODSs). ODSs have very long lifetimes in the stratosphere (some as long as 100 years); they are lofted throughout the stratosphere from the tropical troposphere, transported into the middle and high latitudes, and recirculate, providing chlorine (and bromine) atoms for chemical ozone destruction (WMO, 2011; Rigby et al., 2013).

Analyses of interannual and long-term variability in total column ozone on regional (e.g., Mäder et al., 2007; Rieder et al., 2010a, b, 2011; Fitzka et al., 2014) and global (e.g., Frossard et al., 2013; Rieder et al., 2013) scales have been presented in a number of recent studies. There is now a broad consensus that long-term negative ozone trends are domi- 
nated by ODSs, while short-term trends and variability, particularly at midlatitudes, are also significantly influenced by synoptic-scale meteorological variability (e.g., Steinbrecht et al., 1998; Shepherd, 2008), decadal climate variability (e.g., Chandra et al., 1996; Hood, 1997) and dynamical modes such as the El Niño-Southern Oscillation (ENSO) (e.g., Brönnimann et al., 2004; Ziemke et al., 2010; Hood et al., 2010; Gabriel et al., 2011), the North Atlantic Oscillation (NAO)/Arctic Oscillation (AO) (e.g., Appenzeller et al., 2000; Thompson and Wallace, 2000), and volcanic eruptions (e.g., Jaeger and Wege, 1990; Solomon, 1999; Robock, 2000; Mäder et al., 2007). For the European sector it has been reported that dynamical variability accounts for about a third of the observed ozone changes between the 1970s and 1990s (e.g., Mäder et al., 2007; Wohltmann et al., 2007). The particular importance of dynamical changes for column ozone at midlatitudes has also been highlighted in more recent work that attributes the slight increase in column ozone since the 1990s primarily to dynamics and to a lesser extent to the decrease in ODSs (after their peak around 1997) (e.g., Harris et al., 2008; Hegglin and Shepherd, 2009; WMO, 2007, 2011).

In addition, recent work analyzing the tails of the ozone distribution (i.e., the extremes) in relation to the bulk properties (i.e., the mean) has shown that analysis of the tails allows for a more systematic attribution of ozone changes to dynamical features than mean value analysis can achieve (e.g., Rieder et al., 2010a, b, 2011, 2013; Frossard et al., 2013). These studies also showed that even moderate NAO and ENSO events can have significant effects on the midlatitude ozone field.

Furthermore, while column ozone at northern midlatitudes reached its lowest values in the early 1990s following the 1991 eruption of Mt. Pinatubo, it has been noted that the effect of this eruption was partially masked by atmospheric dynamics in the Southern Hemisphere (e.g., Schnadt Poberaj et al., 2011; Rieder et al., 2013), again emphasizing the importance of atmospheric dynamics to ozone trends and variability.

In this paper we attempt to assess the information contained in the integrated total ozone column derived from the continental US network of Dobson measurements. We discuss interannual variability in column ozone, how it has changed over the last 50 years, what controls it, and how trends are statistically related to dynamical and chemical proxies.

\section{Data}

\subsection{Ground-based total ozone data sets}

Continuous measurements of total column ozone (TOC) over the continental United States began in the early 1960s. Individual measurements were also made earlier at some sites, but more sporadically and mainly in conjunction with the International Geophysical Year 1957.
The backbone of the World Meteorological Organizations (WMO) ozone monitoring network is the Dobson ozone spectrophotometer, an instrument developed in the 1920s specifically for high-accuracy measurements of total column ozone (e.g., Dobson, 1957, 1968). The concept of the Dobson measurement is the differential absorption of ozone at selected wavelengths in the solar ultraviolet spectrum. Two pairs, where one spectral range absorbs light more strongly than the other, are combined to minimize the effect of aerosol interference on the measurements. Measurements made using the direct solar beam are used to determine the TOC based on Lambert-Beer law, while measurements made with the scattered light from the zenith are converted to a TOC value based on the statistics of quasi-simultaneous measurements of both direct sun and zenith.

Operational instrument calibration is maintained by monthly tests with reference and discharge lamps, plus regular intercomparison with two standard instruments: D083 (world primary standard) or D065 (world secondary standard). The calibration of the primary standard is maintained by Langley Plot Campaigns at the National Oceanic and Atmospheric Administration's Earth System Research Laboratory Mauna Loa Observatory (Hawaii).

In the contiguous USA, column ozone has been measured routinely at five observational sites (Bismarck, ND; Boulder, CO; Caribou, ME; Wallops Island, VA; Nashville, TN) since the 1960s. In this study we analyze the total ozone records from these five sites spanning from the 1960s through 2012. A detailed overview on geographical location and information on record length, data completeness and time series properties of the individual station records is provided in Fig. 1.

\subsection{Proxies for atmospheric dynamics}

There is now a broad consensus that long-term trends in total ozone are driven primarily by changes in the atmospheric concentration of ODSs (WMO, 2011). Nevertheless, active research in the field has shown that besides ODSs, several other processes have significant influence on total ozone changes and variability. The 11-year solar cycle, the quasibiennial oscillation (QBO) and volcanic eruptions are among the most prominent explanatory variables often used to describe the influence of atmospheric variability on column ozone (WMO, 2011). At midlatitudes other dynamical features also show a significant influence on column ozone on seasonal and interannual timescales. In particular, synopticscale meteorological variability, described by, for example, the NAO (e.g., Appenzeller et al., 2000; Orsolini and DoblasReyes, 2003; Rieder et al., 2010a, 2011; Frossard et al., 2013) and climate modes such as ENSO (e.g., Rieder et al., 2010a, 2013; Brönnimann et al., 2004), has been shown to significantly influence ozone variability and trends.

In the present study we focus particularly on the influence of atmospheric dynamics on variability and trends in 


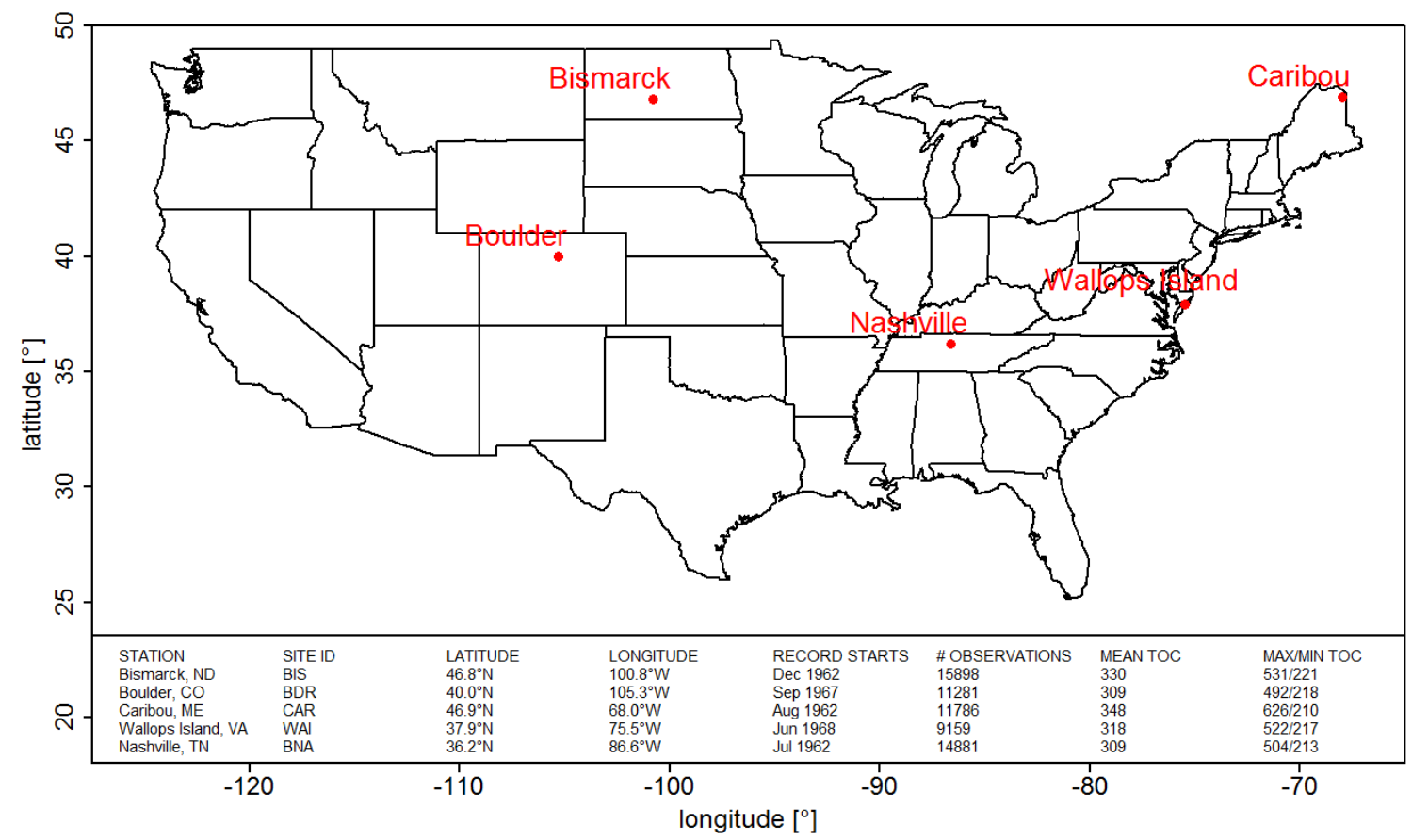

Figure 1. Geographical overview and site-specific information for the USA long-term Dobson total ozone monitoring sites.

column ozone over the USA. To this aim we use a set of indices describing ENSO and NAO modes on a seasonal basis in the statistical analysis. For ENSO we are using the seasonal NINO3.4 index provided by NOAA's Climate Prediction Center - available at http://www.cpc.ncep.noaa. gov/data/indices/3mth.nino34.81-10.ascii.txt. For the NAO we are using the PC-based index (time series of the principal components (PC) of the leading empirically determined orthogonal function (EOF) of seasonal sea level pressure anomalies over the Atlantic sector $\left(20^{\circ} \mathrm{N}-80^{\circ} \mathrm{N}, 90^{\circ} \mathrm{W}-\right.$ $40^{\circ} \mathrm{E}$ )) provided by the NCAR/UCAR climate data center - available at https://climatedataguide.ucar.edu/climate-data/ hurrell-north-atlantic-oscillation-nao-index-pc-based.

\section{Methods}

\subsection{Extreme value statistics}

Recent work has introduced concepts of statistical extreme value theory (EVT) into the field of total ozone research (Rieder et al., 2010a, b, 2011, 2013; Frossard et al., 2013; Fitzka et al., 2014). Here we build on these methodologies to analyze events of extremely low and high ozone (termed ELOs and EHOs, respectively) in the US long-term total ozone records.

The generalized Pareto distribution (GPD) is a commonly used distribution in the framework of extreme value theory (e.g., Davison and Smith, 1990; Ribatet et al., 2009) because it arises as the natural distribution for the exceedance of a random variable (here total ozone) over a threshold. Below we briefly describe the modeling procedure for values over a threshold. Note that the modeling for values below a threshold is precisely the same; the only thing to be done is to negate the values and apply exactly the same procedure as for values above a high threshold as $\min \left(x_{i}\right)=-\max \left(-x_{i}\right)$.

The GPD, which is the limiting distribution of exceedances over a threshold, is defined as

$F(x)=1-\left[1+\xi \frac{x-u}{\sigma}\right]^{-\frac{1}{\xi}}$,
$\sigma>0, x>u, 1+\xi \frac{x-u}{\sigma}>0$,

where $x$ are daily data (here total ozone), $u$ is the threshold value, and $\sigma$ and $\xi$ are the scale (a measure of the spread of the distribution of $x$ ) and shape (which is determining the shape of the distribution rather than shifting it, as $u$ does, or shrinking/stretching it, as $\sigma$ does) parameters, respectively.

Threshold values $u$ are determined on a monthly basis and interpolated to daily values following the procedure described by Rieder et al. (2010b). Thresholds for ELOs and EHOs, as well as long-term monthly mean values for the five US sites, are shown in Fig. 2.

Here the well-known seasonal cycle with ozone minima in fall and maxima in spring, as well as the latitudinal dependence of total ozone mean values and thresholds (i.e., higher TOC at northern sites (Bismarck and Caribou) due to transport of ozone-rich air from high latitudes), is visible. 

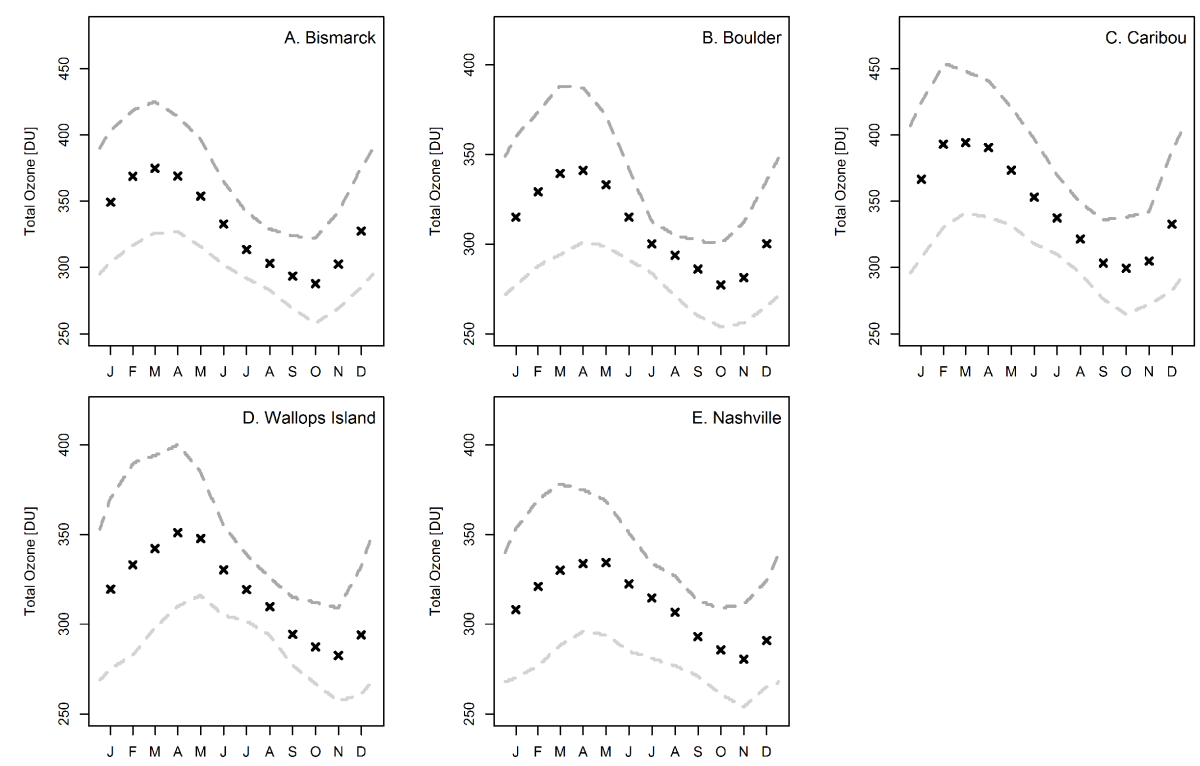

Figure 2. Thresholds for extreme highs (EHOs, dark-grey dashed lines) and lows (ELOs, light-grey dashed lines) of total ozone and climatological monthly means of total ozone (black crosses) at (a) Bismarck, (b) Boulder, (c) Caribou, (d) Wallops Island, and (e) Nashville.

Following Rieder et al. (2010b), total ozone observations at the individual US sites are categorized into three groups (see Eqs. 2-4):

$$
\begin{aligned}
& \mathrm{ELO}=\left\{x(t): x(t)<u_{\mathrm{LOW}}(t)\right\}, \\
& \mathrm{EHO}=\left\{x(t): x(t)>u_{\mathrm{HIGH}}(t)\right\}, \\
& \mathrm{NEO}=\left\{x(t): u_{\mathrm{LOW}}(t) \leq x(t) \leq u_{\mathrm{HIGH}}(t)\right\},
\end{aligned}
$$

where $x(t)$ is the column ozone amount at a given day; $u_{\mathrm{LOW}}(t)$ and $u_{\mathrm{HIGH}}(t)$ are the thresholds for low and high ozone on a given day; and ELO, EHO, and NEO denote days with low, high, and non-extreme ozone, respectively. The frequency of low- and high-ozone events is discussed below in the context of dynamical features (see Sect. 4.1).

\subsection{Seasonal trend decomposition of time series based on LOESS (STL)}

Seasonal trend decomposition of time series based on LOESS (LOcally wEighted Scatterplot Smoothing) (e.g., Cleveland et al., 1990) decomposes a data record (here ozone) into seasonality, trend, and residual components. When applied to the US column ozone data it returns a wellknown picture: (i) a strong seasonal cycle with maxima in spring and minima in winter/fall, in accordance with the understanding of the influence of the Brewer-Dobson circulation on column ozone (transport of ozone-rich air towards northern midlatitudes during boreal winter); (ii) a negative trend component dominated by the influence of ODSs on column ozone; and (iii) a highly variable residual component representing the effects of local-scale meteorology on column ozone. An example of an STL decomposition for the site in Boulder, CO, is shown in Fig. S1 in the Supplement of this article. For a more detailed description of the STL procedure we refer the interested reader to the paper of Cleveland et al. (1990), which describes the method.

STL-trend components represent smoothed TOC residuals after the seasonal cycle is removed and are thus not reliable measures for TOC trend analysis. Statistical trend analysis in this manuscript is solely based on linear regression analysis (see Sect. 4.4). Here we utilize STL because the resulting trend component provides a more detailed picture of the seasonal and interannual variability in the overall TOC time series compared to, for example, a simple linear trend component, and thus is suitable for the secondary assessment of "fingerprints" of NAO and ENSO events as long-term time series variability is preserved.

\section{Results}

The main goal of this paper is to analyze the influence of dynamical features such as NAO and ENSO on column ozone over the USA. To this aim, EVT modeling and STL decomposition are applied to the long-term total ozone time series to derive fingerprints of the dynamical covariates.

\subsection{Fingerprints of NAO and ENSO in the frequency distribution of extreme events}

In Sect. 3.1 we described the classification of total ozone observations into days with extremely low, extremely high, and non-extreme ozone. Here we focus on the frequency distribution of the extremes and analyze the influence of ENSO and NAO events on column ozone at the five US ozone monitoring sites. As the general features are very similar among 
the individual sites, we mainly show the results for Boulder and Caribou, which give the envelope of column ozone observations over the USA, in the main body of the paper. For convenient reference, illustrations for other sites are available in the Supplement for this article.

In Figs. 3 and 4 we plot the observed frequency of ELOs, NEOs, and EHOs as time series for Boulder and Caribou (the results for the remaining sites are shown in Figs. S2-S4). Next, we turn to fingerprints of atmospheric dynamics in the frequency distribution of EHOs and ELOs at these sites.

First, we turn to the North Atlantic Oscillation, the leading mode in the Atlantic sector, which influences the direction and intensity of the tropospheric jet stream (e.g., Orsolini and Limpasuvan, 2001) and represents the main driver of the interannual variability in storm tracks during the cold season (e.g., Lau, 1988). A positive NAO phase leads to lower ozone over Europe and the USA and higher ozone over the Labrador Sea and Greenland, and vice versa for a negative NAO phase (see Rieder et al., 2010b, and references therein, as well as Frossard et al., 2013, for a spatial representation of NAO influence on column ozone at northern midlatitudes).

The North Atlantic Oscillation in its negative phase (NAO index $<-1$, marked with blue (winter) and light blue (spring) dots in Figs. 3 and 4) leads to higher column ozone over the United States during winter and spring. Conversely, a fingerprint of the NAO in its positive phase (NAO index $>1$, marked with red (winter) and orange (spring) dots in Figs. 3 and 4) is seen as lower ozone over the USA in the individual station records. Over the study period (1963-2012), the NAO was in a strongly positive phase (NAO index >1) 16 times during winter and 12 times during spring. While all but one of the wintertime events are captured in the frequency of ELOs at multiple sites, 2 out of the 12 spring events remain undetected (1982 and 1994) at any of the five US sites (see Fig. 6). The correlation analysis confirms the relationship between column ozone and the NAO phase (see Table 1).

In both winter and spring the NAO index correlates negatively with the frequency of EHOs and positively with the frequency of ELOs, indicating an increase (decrease) in the frequency of high-ozone events during a negative (positive) NAO phase and vice versa for low-ozone events, manifested also in the seasonal means.

It has been noted that the NAO has tended towards a more positive phase in recent decades (e.g., Hurrell, 1995; Thompson and Wallace, 2000), concomitant with a strengthening of the northern polar vortex. Nevertheless, a strongly negative NAO phase (NAO index $<-1$ ) is found 10 times during winter and 5 times during spring (roughly half the rate of positive phase events) in 1963-2012. Out of the 10 wintertime events, 8 are discernible in the frequency distribution of extreme total ozone, with the winters of 1973/74 and 2010/11 being absent. The missing NAO fingerprint in winter $2010 / 11$ is not surprising given the unusual dynamical conditions in the Arctic in this year, which led to a particularly strong stratospheric polar vortex and record Arctic ozone losses (e.g.,
Table 1. Correlation of the NAO index and the average number (no.) of EHOs and ELOs and mean column ozone (TOC) on a seasonal basis at the five US long-term total ozone monitoring sites.

\begin{tabular}{lccc}
\hline \multirow{2}{*}{ Season/station } & \multicolumn{3}{c}{ Correlation with NAO index } \\
& no. EHOs & no. ELOs & Mean TOC \\
\hline DJF & & & \\
\hline Bismarck & -0.44 & 0.40 & -0.53 \\
Boulder & -0.26 & 0.29 & -0.34 \\
Caribou & -0.53 & 0.33 & -0.61 \\
Wallops Island & -0.28 & 0.38 & -0.52 \\
Nashville & -0.53 & 0.33 & -0.48 \\
\hline MAM & & & \\
\hline Bismarck & -0.21 & 0.22 & -0.29 \\
Boulder & -0.10 & 0.10 & -0.21 \\
Caribou & -0.16 & 0.10 & -0.21 \\
Wallops Island & -0.10 & 0.23 & -0.21 \\
Nashville & -0.27 & 0.10 & -0.20 \\
\hline
\end{tabular}

Manney et al., 2011), counteracting the dynamic enhancement of column ozone due to the NAO. Out of the five springtime negative NAO events, three can be identified in (most of) the five US monitoring sites, with 2005 and 2006 missing. As was the case in 2011, the particularly cold conditions in the Arctic spring of 2005 likely contribute to the missing NAO fingerprint. Differences in the occurrence and detection frequency of NAO fingerprints are captured in the correlation analysis, with overall stronger correlations during winter than spring. This is further explored in Fig. 7, which shows the fraction of EHOs and ELOs during wintertime positive and negative NAO events: more (fewer) EHOs during NAO$(\mathrm{NAO}+)$ phases and vice versa for ELOs.

The NAO fingerprints identified in the US column ozone records are in broad agreement with those for European sites and satellite data. Appenzeller et al. (2000) were among the first to report on the influence of the NAO on column ozone over Europe, based on their analysis of the world's longest total ozone record: Arosa, Switzerland. Rieder et al. (2010a) extended these investigations toward low and high ozone values and Rieder et al. (2011) documented the influence of the NAO in its positive (reduced column ozone, reduced frequency of high-ozone events) and negative (increased column ozone, increased frequency of high-ozone events) phases for five European ground-based sites in 1970 2010. These authors report a similar number of detected fingerprints and occasional misses at individual sites due to local effects. Frossard et al. (2013) extended investigations to larger spatial scales by analyzing the NIWA assimilated total ozone data set in 1979-2007. These authors report that the fingerprint of the NAO is of similar spatial extent for both mean values and ozone extremes but that the magnitude of influence on total ozone is larger for extremes than mean values. These results are in broad agreement with those pre- 

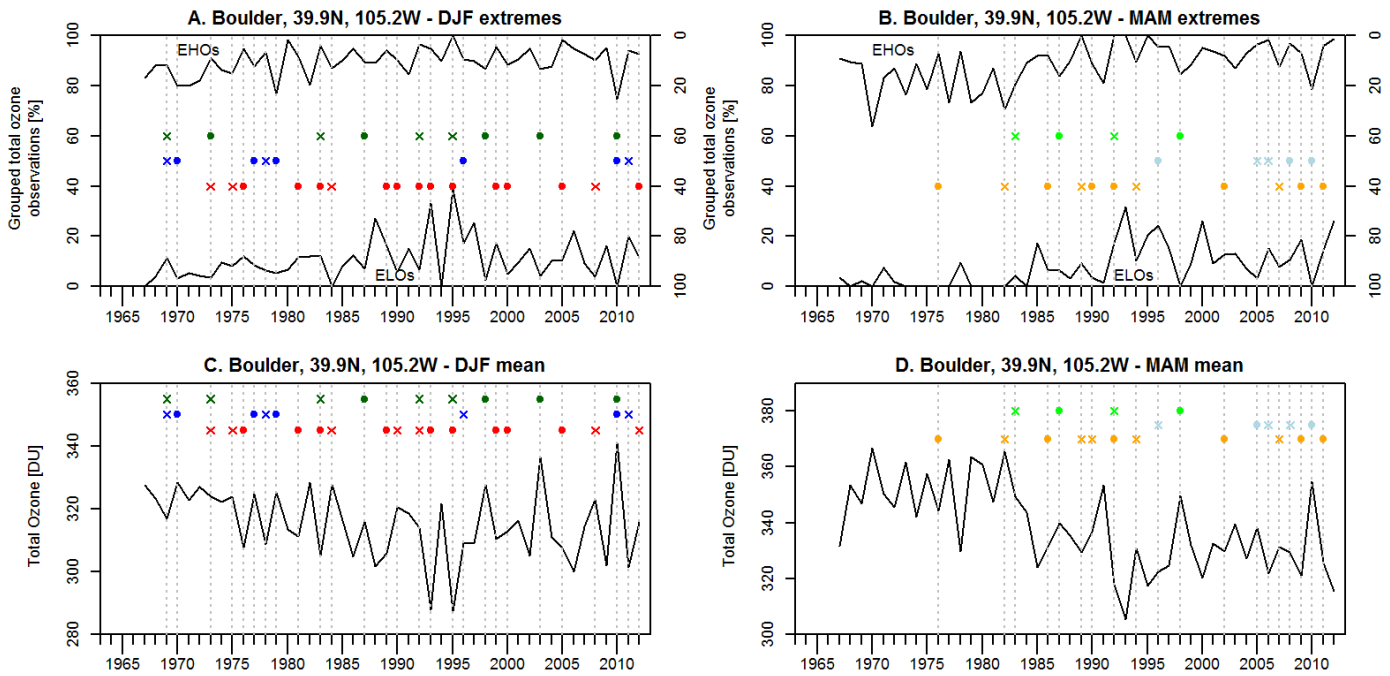

Figure 3. "Fingerprints" of the NAO and ENSO as detected for Boulder in the seasonal frequency time series of EHOs (right axis, top to bottom) and ELOs (left axis, bottom to top) for (a) winter (DJF) and (b) spring (MAM). Panels (c) and (d) show fingerprints in seasonal mean column ozone. Filled circles denote visible fingerprints and crosses denote not visible fingerprints. NAO positive (negative) phase is indicated for winter in red (blue) and for spring in orange (light blue); ENSO positive phase is indicated for winter (spring) in green (light green).
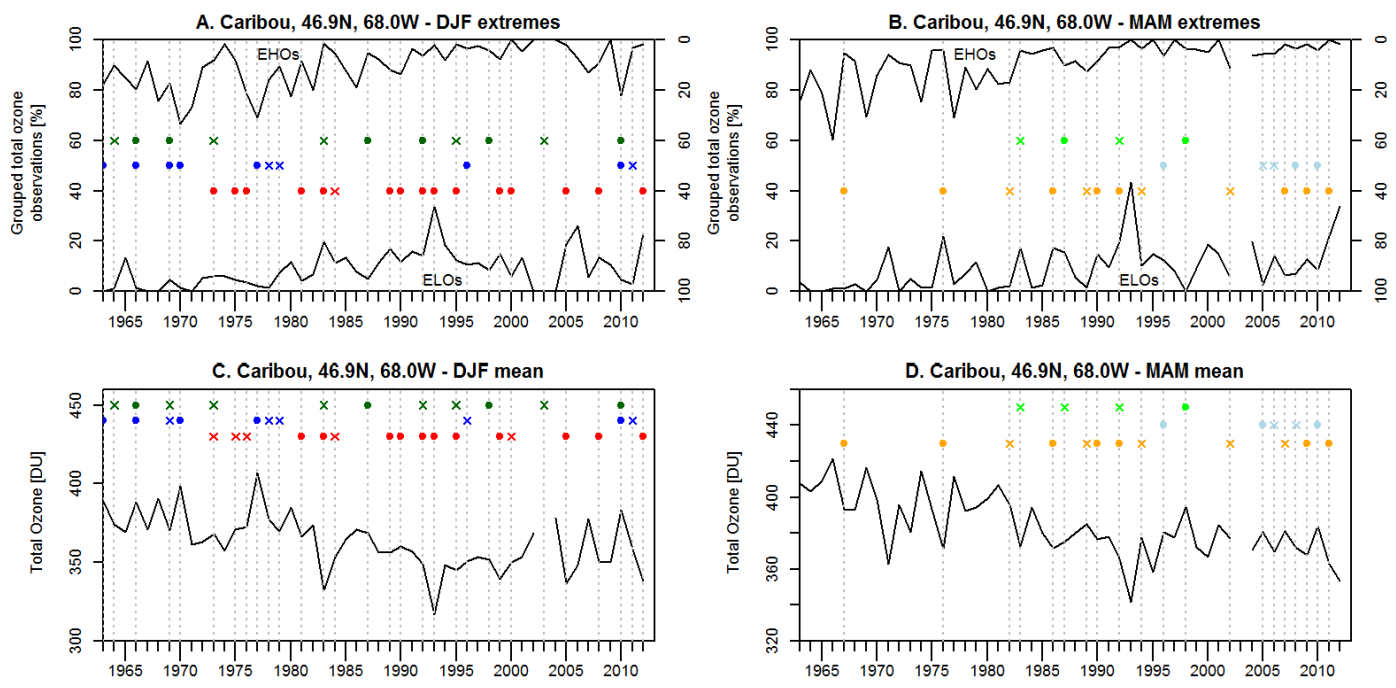

Figure 4. As Fig. 3 but for Caribou.

sented here for the US long-term ozone records, documenting the significant influence of the NAO on column ozone variability throughout northern midlatitudes.

Next we turn to the El Niño-Southern Oscillation. Warm ENSO events are triggered by a high contrast between tropical and extratropical Pacific sea-surface temperatures, which are known to affect midlatitudes (in particular the North Pacific) via changes in the Hadley cell and Rossby wave generation (e.g., Trenberth, 1998; Alexander et al., 2002). During warm ENSO events, the meridional circulation in the stratosphere leads to enhanced ozone transport from the tropics to middle and high latitudes and a warmer lower stratosphere, both of which tend to increase midlatitude ozone (Rieder et al., 2013, and references therein).

The warm ENSO phase (El Niño, NINO3.4 index >0.7) is, as expected, associated with higher ozone over the USA during winter/spring, visible in the frequency distribution of the extremes. During the study period, moderate to strongly positive ENSO events were recorded 11 times during winter and 4 times during spring. Most wintertime events (except those in 1983, 1992, and 1995) and springtime events (except 1983 and 1992) can be identified in the frequency distribution of ozone extremes. The absence of ENSO fingerprints in the remaining 3 years is consistent with their occurrence imme- 
diately after the two major volcanic eruptions of the last century (El Chichón in 1982 and Mt. Pinatubo in 1991), when the effects of the volcanic eruptions (enhanced ozone depletion on sulfate aerosols) would have masked the dynamical signal. As was the case for the NAO, the ENSO results for the US sites are in good agreement with findings for European sites and satellite data (e.g., Rieder et al., 2010a, 2013), illustrating the importance of ENSO in modulating column ozone at northern midlatitudes. The correlation analysis between ENSO and column ozone (or the frequency of EHOs and ELOs) is less conclusive then for the NAO, probably because of the rather small number of strong ENSO events.

At all sites we find a more consistent presence of fingerprints of NAO and ENSO in extreme values of column ozone (upper panels in Figs. 3 and 4) than in its mean values (lower panels of Figs. 3 and 4). While the extremes show a pronounced response (increasing or decreasing frequency) to the prevailing ENSO and NAO phases, the mean values often do not show large differences compared to neighboring years without ENSO or NAO events. This is particularly evident for $\mathrm{NAO}+$ events, where about twice as many events were detected in the frequency distribution of the extremes than in the seasonal mean values.

\subsection{Fingerprints of atmospheric dynamics in the STL decomposition}

Here we contrast the findings of the EVT-based analysis with results from the STL-decomposition approach. In Fig. 5 we show the anomaly of the trend components of the STL decomposition for the two selected US sites - Boulder and Caribou - as above in the EVT analysis (the results for the remaining sites are shown in Fig. S5). While the overall trend curves show a steady decline that is most pronounced in the 1980s and 1990s, as expected from the strong negative influence of ODSs on column ozone (e.g., WMO, 2011), there is also a large degree of interannual variability in these curves. This variability is not related to seasonality in the ozone field, since the seasonal component has been removed from the data prior to the trend computations within the STL procedure.

As for the EVT analysis we now identify fingerprints of ENSO and NAO events in the STL trend component. The colored vertical bars in Fig. 5a and c mark positive and negative winter- and springtime NAO events. The analysis of the STL trend component shows that positive NAO events are associated with a decreasing tendency in the trend curve, and thus with lower column ozone, while negative $\mathrm{NAO}$ events are associated with an increasing tendency in the STL trend component, and thus with higher column ozone. Figure $5 \mathrm{~b}$ and $\mathrm{d}$ show the corresponding results for warm ENSO events, which tend to enhance column ozone. The good agreement between the results in Fig. 5 with those from the EVT analysis (Figs. 3 and 4) provides further evidence of the significant influence of strong NAO and ENSO events on column ozone variability over the continental USA.

\subsection{Similarities and differences among the individual monitoring sites}

Despite the overall similarity in trends and patterns of variability, it is important to note that fingerprints of individual NAO and ENSO events are not always found at all five stations analyzed. Figure 6 provides a summary of all major ENSO and NAO events over the 1963-2012 time period and their detection (or absence) in the individual station records. Solid squares in Fig. 6 mark fingerprints detected, while open squares mark "absent" fingerprints at individual sites. The majority of ENSO and NAO events are detected at all five US total ozone monitoring sites, but some individual events are not discernible at individual (or multiple) sites such as the negative NAO event of spring 1996. The absence of individual fingerprints is not too surprising given the large spatial distance between individual sites and their regional location (see Fig. 1). The occasional masking of largescale ozone variability by localized synoptic-scale meteorology (e.g., the influence of the subtropical jets and localized tropopause variations) is associated with the regional patterns of advection and convergence or divergence that are related to changes in tropospheric and stratospheric pressure systems as has been previously reported for regions other than the USA (e.g., Koch et al., 2005; Mäder et al., 2007; Wohltmann et al., 2007).

Direct correlations of daily TOC between sites are rather inconclusive due to the difficulty in accounting for local meteorological effects at a station or temporal lags between stations due to transport. Unfortunately, vertical investigations are limited by the absence of vertically resolved ozone profiles at most of the stations (except for Boulder, CO). In addition, seasonal comparisons between years with fingerprints and without are restricted to a small sample size (i.e., a few missing fingerprints on a site basis). Nevertheless, a comparison of cumulative distribution functions (CDFs) on a site basis between neighboring years with and without fingerprints reveals the absence of high- or low-ozone events associated with the NAO or ENSO (see Fig. S6 in the Supplement). Thus, instead of individual effects, we quantify the overall contribution of extremes to seasonal mean column ozone by calculating the influence of ELOs and EHOs at each site.

Several studies have linked the occurrence of multiple tropopauses to Rossby wave breaking events along the subtropical jet (Homeyer and Bowman, 2013, and references therein) and to associated tropospheric intrusions (e.g., Pan et al., 2009). Climatological maxima in multiple tropopause occurrence have been linked to observed changes in vertical profiles of satellite-observed trace gases that are consistent with air from the tropical tropopause layer being drawn into the region between the two tropopauses; specifically, climatological ozone mixing ratios in midlatitude mul- 

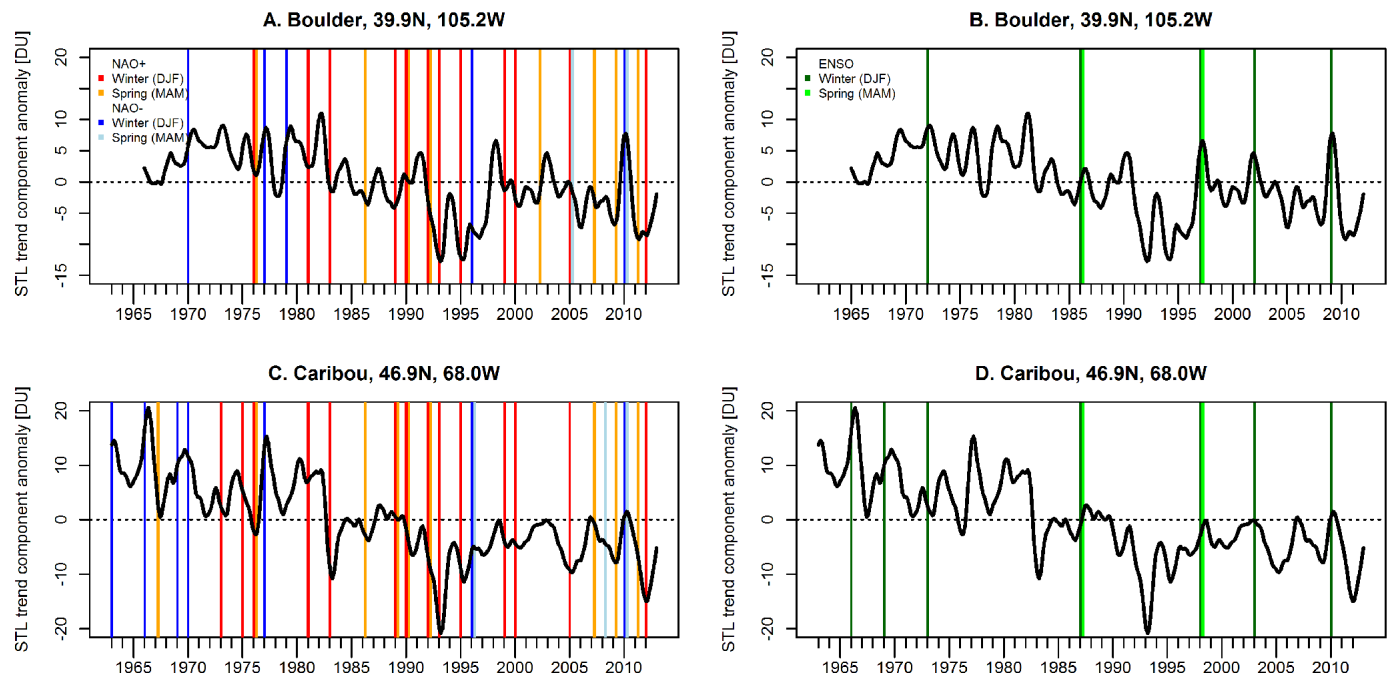

Figure 5. STL-trend component anomaly (in DU) in 1963-2012 for Boulder (top) and Caribou (bottom) with underlying marks (colored vertical bars) for fingerprints of positive and negative NAO modes (left panels) and warm ENSO phases (right panels) on a seasonal basis. NAO positive (negative) phase is indicated for winter in red (blue) and for spring in orange (light blue). The warm ENSO phase is indicated for winter in green and spring in light green.

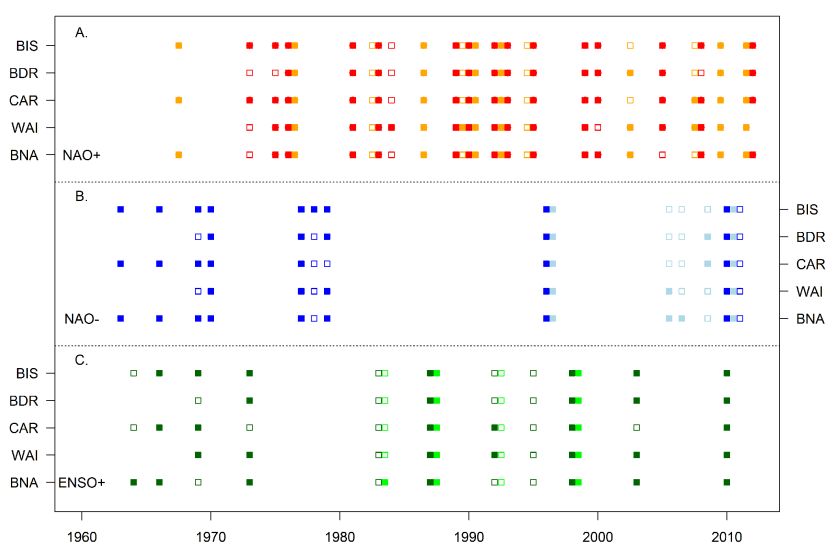

Figure 6. Summary of detected and missed fingerprints at all five US stations for (a) the NAO in its positive phase (winter red, spring orange), (b) the NAO in its negative phase (winter, blue; spring, light blue), and (c) ENSO in its warm phase (winter, red; spring, orange). Filled squares mark visible fingerprints, while open squares mark non-visible fingerprints.

tiple tropopause regions are substantially lower than those in regions with a single tropopause (Schwartz et al., 2015). Schwartz et al. (2015) estimated that in Northern Hemisphere winter midlatitudes, when multiple tropopauses are most common, climatological ozone values can be as much as $20 \%$ lower than they would be without multiple tropopauses.

These results are consistent with the observed association of lower column ozone with multiple tropopauses (e.g., Castanheira et al., 2012; Mateos et al., 2014). Mateos et al. (2014) also noted more common occurrence of such tropospheric intrusion events during NAO positive phases, sug-
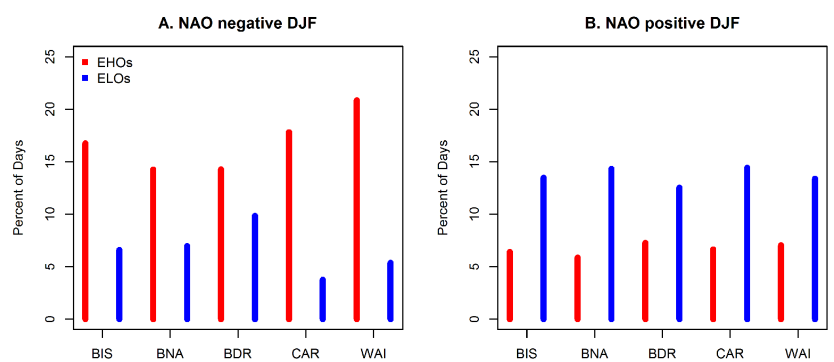

Figure 7. Average fraction of days (in \%) identified as EHO and ELO during (a) negative and (b) positive NAO phases in the winter (DJF) season.

gesting a role for dynamical modes such as NAO and ENSO in modulating multiple tropopause occurrence and thus their corresponding effects on ozone.

In addition, there is a maximum in multiple tropopause occurrence frequency over the USA in winter and spring, extending poleward from the region where upper tropospheric jets are most common (Manney et al., 2014). Boulder, Nashville, and Wallops Island are near the latitude of maximum multiple tropopause occurrence just poleward of the subtropical upper tropospheric jet, while Bismarck and Caribou are at the northern edge of the region of enhanced multiple tropopause activity (Manney et al., 2014) and are thus less frequently affected by processes in multiple tropopause regions.

The absence of individual fingerprints on a site basis and their underlying cause is of general interest but beyond the spatial and climatological scope of the presented study. Nevertheless, further analysis (including vertical information 
from sounding profiles) is suggested for future site-specific analysis addressing effects of local dynamics on column ozone variability.

\subsection{Influence of extreme events on ozone mean values and trends}

In this section we turn the focus to column ozone trends at the five US Dobson sites.

To analyze the influence of extremes (both low and high) on ozone trends we contrast linear trends for the entire observational time series (i.e., all observational data included) with trends for time series with extremes removed. We focus on two main time periods: 1970-1995, with almost linearly increasing ODSs, which includes the peak in ozone depletion (following the Mt. Pinatubo eruption), and 1996-2010, which extends from the maximum in ODSs $(\sim 1996 / 1997)$ to current conditions. Results for each site during winter and spring are given in Table 2. During the 1970-1995 period, with almost linearly increasing ODSs and significant midlatitude ozone losses in the early 1980s and 1990s (following the El Chichón and Mt. Pinatubo eruptions), ozone trends vary between -2.8 and $-4.8 \%$ per decade among the sites and seasons (Table 2). All sites except Caribou show larger negative trends in spring than in winter, consistent with results from European midlatitude sites (e.g., Rieder et al., 2010b, 2011). We argue that this qualitative difference between Caribou and the other US sites is determined by geography. Caribou is the northernmost US monitoring site and is thus more frequently affected by transport of air masses out of the Arctic polar regions in winter and spring than the other stations; such Arctic air may, in particularly cold winters, carry the signature of chemical ozone depletion. The more southerly sites are usually most strongly influenced by midlatitude ozone-rich air masses (e.g., Manney et al., 2014), though they may also show effects of transport of low-ozone air from low latitudes and accompanying troposphere-to-stratosphere exchange.

Comparing the entire observational records with those with extremes removed, we find that trends are only about half as strong in the latter case. This is particularly interesting as no statistically significant trend (at a $95 \%$ level) is found for the magnitude of EHOs or ELOs over 1970-1995. The individual time series show the well-known pattern of large interannual variability but no robust increase (or decrease) in the average magnitude of the extremes themselves. Thus the influence of extremes on seasonal mean column ozone (see below) can be understood as a function of their occurrence frequency, driven by chemical ozone depletion and dynamics.

Turning now to the more recent past, i.e., 1996-2010 (Table 2), we find positive trends at most sites, an anticipated result since stratospheric chemistry in this period is impacted by slowly but steadily declining ODSs. The key interest in the trends for 1996-2010 is thus not the sign of the trends but their significance. Observational and modeling studies suggest that chemical ozone depletion ceased to increase around the turn of the century (e.g., WMO, 2011), but whether significant ozone recovery has started is still undetermined. Positive trends at the majority of sites indicate that ozone has stopped declining over the USA, particularly during winter, suggesting that chemical depletion may have ceased (Table 2). Nevertheless, since the trend estimates over the 15year period of 1996-2010 are not significant at the $95 \%$ level (see $p$ values in Table 2), there is no clear evidence that significant ozone recovery has started yet. As was the case for 1970-1995, the trends are much smaller (by a factor of 2-3) if extremes are removed from the records. Again we investigate whether significant changes occurred in the extremity of ELOs and EHOs, and, as for the 1970-1995 period, we find large interannual variability in the magnitude of lows and highs (driven by dynamics and chemistry) but no significant trends at rigorous test levels (i.e., $95 \%$ ).

Discriminating the effects of the individual dynamical proxies on column ozone is difficult because (i) fingerprints for multiple proxies are found in several years (e.g., a strongly positive NAO and a warm ENSO phase) and (ii) the occurrence frequency of the individual fingerprints is highly variable. Also correlations between sites are rather noisy on daily timescales (local effects) and seasonal comparisons between years with fingerprints and without are restricted to a small sample size (i.e., too few missing fingerprints on a site basis). Thus, instead of individual effects, we quantify the overall contribution of extremes to seasonal mean column ozone by calculating the influence of ELOs and EHOs at each site:

$I_{\mathrm{ELOs}}=\left(\frac{M_{\mathrm{S}}-M_{\mathrm{SELO}(\mathrm{ex})}}{M_{\mathrm{S}}}\right) \cdot 100$,
$I_{\mathrm{EHOs}}=\left(\frac{M_{\mathrm{S}}-M_{\mathrm{SEHO}(\mathrm{ex})}}{M_{\mathrm{S}}}\right) \cdot 100$,

where $I_{\mathrm{ELOs}}\left(I_{\mathrm{EHOs}}\right)$ is the influence of extremely low (high) total ozone on seasonal mean column ozone $\left(M_{\mathrm{S}}\right)$ in percent, and $M_{\mathrm{SELO}(\mathrm{ex})}\left(M_{\mathrm{sEHO}(\mathrm{ex})}\right)$ is the seasonally averaged column ozone with ELOs (EHOs) excluded from the time series. In Figs. 8 and 9 we show the influence of ELOs and EHOs on winter and spring column ozone, respectively. While EHOs are the dominant influence in the early and late parts of the station records, the time period from 1980 to 2000 is dominated by the influence of ELOs, consistent with the nearly linear increase in ODSs and their importance to column ozone changes in this time period. During this period of strong ozone depletion, however, individual years still show a net positive effect of the extremes on seasonal mean column ozone, highlighting the importance of dynamical factors, such as warm ENSO events (e.g., spring 1986 and 1998), on column ozone variability. The influence of ELOs and EHOs on seasonal mean ozone is bounded by 
Table 2. Seasonal linear trends (in \% per decade) for observed and extremes removed winter (DJF) and spring (MAM) column ozone time series in 1970-1995 and 1996-2010 at the five US ozone monitoring sites. Standard errors are given in parentheses; $p$ values are provides as superscripts.

\begin{tabular}{lllll}
\hline & \multicolumn{4}{c}{ Trend (in \% per decade) } \\
\cline { 2 - 5 } Season/station & Observations & No extremes & Observations & No extremes \\
\cline { 2 - 5 } DJF & & & \\
\hline Bismarck & $-2.9( \pm 0.8)^{0.001}$ & $-1.3( \pm 0.4)^{0.005}$ & $+3.6( \pm 2.2)^{0.127}$ & $+2.0( \pm 1.3)^{0.145}$ \\
Boulder & $-2.8( \pm 0.8)^{0.002}$ & $-1.3( \pm 0.5)^{0.034}$ & $+1.3( \pm 1.9)^{0.532}$ & $+0.2( \pm 1.0)^{0.897}$ \\
Caribou & $-3.8( \pm 1.1)^{0.003}$ & $-0.9( \pm 0.7)^{0.205}$ & $+3.1( \pm 2.4)^{0.277}$ & $+2.1( \pm 2.0)^{0.308}$ \\
Wallops Island & $-2.9( \pm 1.1)^{0.017}$ & $-0.7( \pm 0.6)^{0.434}$ & $+3.8( \pm 2.4)^{0.136}$ & $+2.0( \pm 1.1)^{0.142}$ \\
Nashville & $-2.6( \pm 1.0)^{0.016}$ & $-1.3( \pm 0.6)^{0.023}$ & $+2.5( \pm 2.2)^{0.294}$ & $+0.5( \pm 1.1)^{0.658}$ \\
\hline MAM & & & & \\
\hline Bismarck & $-4.8( \pm 0.7)^{0.001}$ & $-2.3( \pm 0.5)^{0.001}$ & $+0.8( \pm 1.8)^{0.685}$ & $+0.3( \pm 1.1)^{0.890}$ \\
Boulder & $-4.3( \pm 0.9)^{0.001}$ & $-2.3( \pm 0.5)^{0.001}$ & $+1.2( \pm 1.9)^{0.535}$ & $+0.6( \pm 0.9)^{0.532}$ \\
Caribou & $-3.2( \pm 1.1)^{0.004}$ & $-1.7( \pm 0.5)^{0.004}$ & $-1.1( \pm 1.2)^{0.395}$ & $-0.5( \pm 0.8)^{0.225}$ \\
Wallops Island & $-3.5( \pm 1.0)^{0.001}$ & $-1.9( \pm 0.6)^{0.003}$ & $-0.2( \pm 2.2)^{0.928}$ & $+0.0( \pm 1.2)^{0.993}$ \\
Nashville & $-3.2( \pm 1.0)^{0.005}$ & $-1.9( \pm 0.6)^{0.003}$ & $+3.6( \pm 2.1)^{0.101}$ & $+1.0( \pm 1.1)^{0.258}$ \\
\hline
\end{tabular}

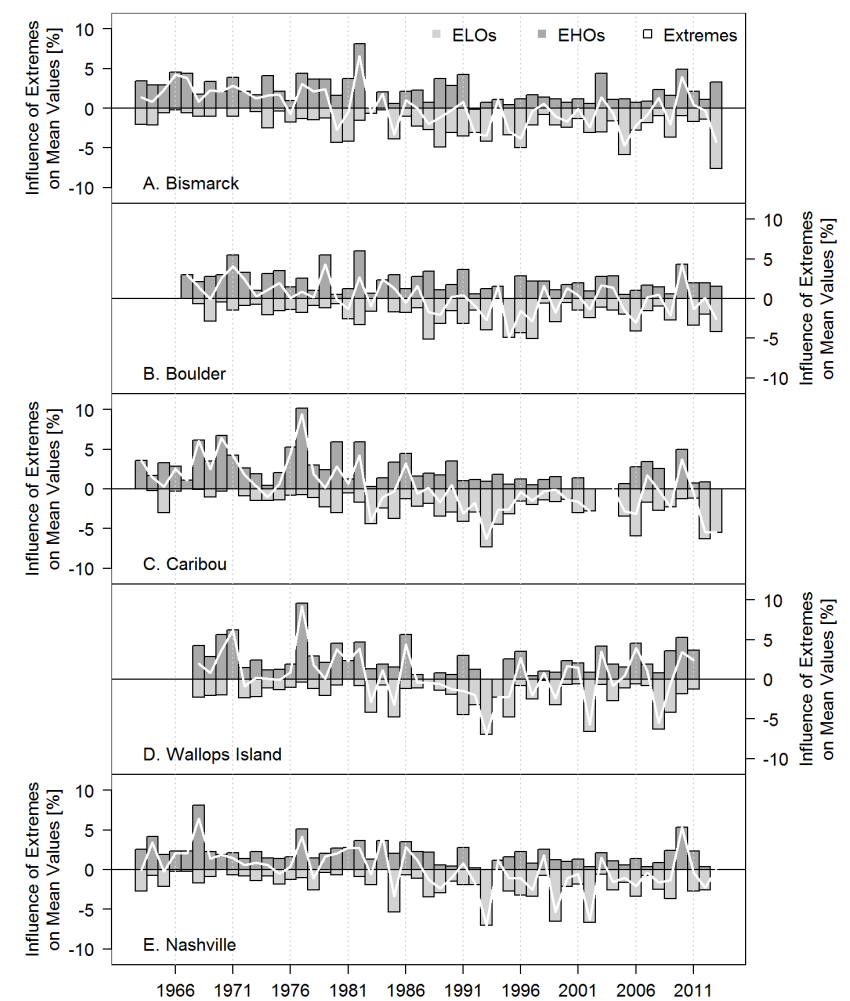

Figure 8. Influence (in \%) of events of extremely low (ELOs, light histogram) and high (EHOs, dark histogram) ozone and net influence of extremes (white curve) on winter (DJF) mean ozone at (a) Bismarck, (b) Boulder, (c) Caribou, (d) Wallops Island, and (e) Nashville.
Table 3. Pattern correlation of the net influence of extremes on winter (DJF) and spring (MAM) mean column ozone among the five US ozone monitoring sites. For station code see Fig. 1.

\begin{tabular}{lccccc}
\hline \multicolumn{7}{l}{ Season/stations } & & & \\
\hline DJF & BIS & BDR & CAR & WAI & BNA \\
\hline BIS & $\mathrm{X}$ & 0.64 & 0.48 & 0.42 & 0.6 \\
BDR & 0.64 & $\mathrm{X}$ & 0.51 & 0.34 & 0.58 \\
CAR & 0.48 & 0.51 & $\mathrm{X}$ & 0.69 & 0.63 \\
WAI & 0.42 & 0.34 & 0.69 & $\mathrm{X}$ & 0.69 \\
BNA & 0.6 & 0.58 & 0.63 & 0.69 & $\mathrm{X}$ \\
\hline MAM & & & & & \\
\hline BIS & $\mathrm{X}$ & 0.76 & 0.69 & 0.59 & 0.6 \\
BDR & 0.76 & $\mathrm{X}$ & 0.61 & 0.68 & 0.65 \\
CAR & 0.69 & 0.61 & $\mathrm{X}$ & 0.5 & 0.52 \\
WAI & 0.59 & 0.68 & 0.5 & $\mathrm{X}$ & 0.72 \\
BNA & 0.6 & 0.65 & 0.52 & 0.72 & $\mathrm{X}$ \\
\hline
\end{tabular}

about $\pm 5 \%$, thus about as large as the overall long-term trend values given in Table 2 .

Next we analyze the pattern correlation of the net contribution of the extremes (i.e., $I_{\mathrm{ELOs}}+I_{\mathrm{EHOs}}$ ) among individual sites. The seasonal pattern correlations among individual sites are summarized in Table 3. Pattern correlations are highest for neighboring sites, i.e., Boulder-Bismarck and Nashville-Wallops Island. Caribou is again an exception in this respect, with a seasonally dependent correlation with the other sites. During winter, the correlation at Caribou is highest with the eastern sites (Nashville and Wallops Island), 


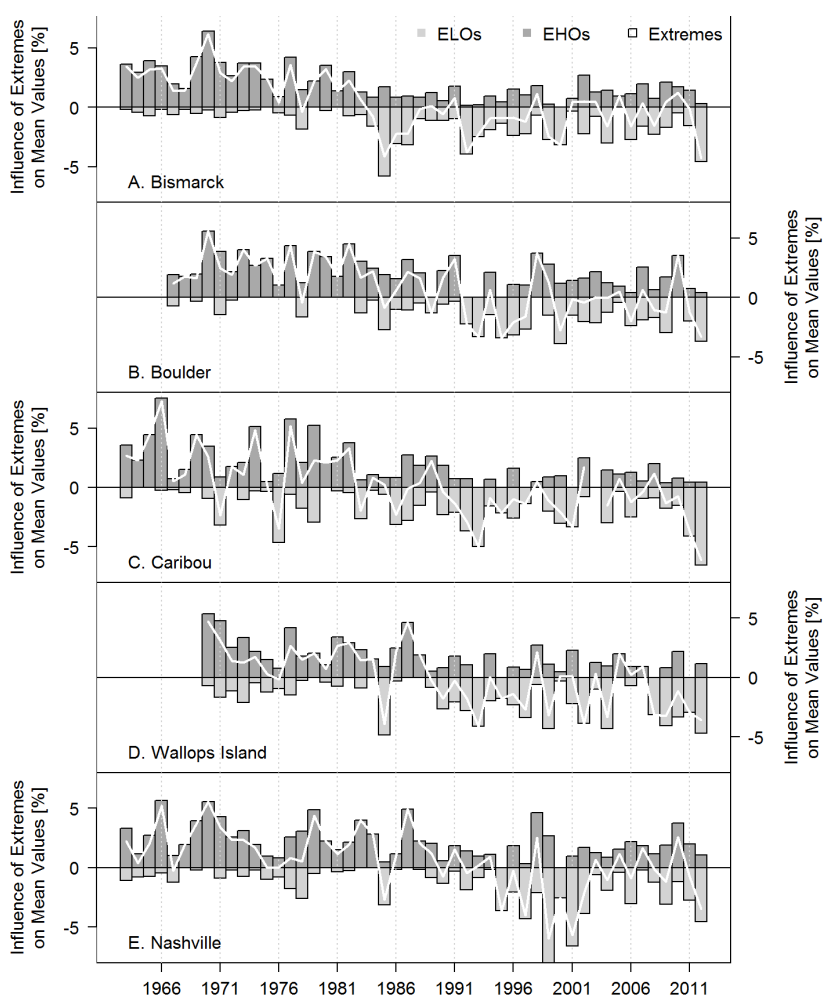

Figure 9. As Fig. 8 but for spring (MAM).

while during spring the correlation is highest with the western sites (Bismarck and Boulder), suggesting that Caribou is under the influence of the same air masses as the eastern/western sites during different seasons. Examinations of the overall correlations for each decade of the record (not shown here) indicates that the correlation between Boulder and Nashville (particularly in winter) increases with time (i.e., it is higher in the 1990s and 2000s than in the 1970s and 1980s), while the correlation between Nashville and Wallops Island slightly decreased in recent decades (in both winter and spring), consistent with Boulder and Nashville being more frequently influenced by similar air masses in recent years. Recent operational changes at Caribou, resulting in reduced sampling frequency, significantly affect the correlation between Caribou and Wallops Island, thus highlighting the importance of continuous and frequent ozone observations for both trend analysis and assessment of relationships between measurements at different sites.

\section{Discussion and conclusions}

In this study we analyze data from the five long-term Dobson stations across the contiguous USA to investigate the influence of the North Atlantic Oscillation (NAO) and the El Niño-Southern Oscillation (ENSO) on total ozone variability and trends since the 1960s. In addition to standard evaluation techniques we utilize a STL-decomposition method
(Seasonal Trend decomposition procedure based on LOESS) and statistical extreme value theory (EVT) to address the temporal variability and trends in the Dobson data in relation to synoptic-scale meteorological and climate variability.

The results show that fingerprints of the dynamical features are better captured in the tails (i.e., the extremes) than in the bulk (i.e., the mean) of the observational records, a result in broad agreement with earlier work for European monitoring sites (Rieder et al., 2010a, 2011) and satellite data (e.g., Frossard et al., 2013; Rieder et al., 2013). Fingerprints of individual ENSO and NAO events are coherently captured at the majority of the sites, indicating the large-scale influence of these features on column ozone. The observed increase in the frequency of ELOs and decrease in the frequency of EHOs from the 1970s on is in agreement with the notion of increasing ODSs. Further, ELOs are indicative of the extension of the subtropical jet to the north of the station, which brings in tropical air masses with low ozone content, while EHOs are indicative of an equatorward excursion of the polar jet and advection of $\mathrm{O}_{3}$-rich air masses from high latitudes. The changing frequency of ELOs and EHOs is thus in agreement with the notion of the expansion of the tropical band and contraction of the northern polar band (e.g., Hudson et al., 2006; Seidel et al., 2008). During the 1980-2000 period, when ozone depletion was strongest, individual years still show a net positive contribution of the extremes to seasonal mean column ozone, demonstrating the importance of individual negative NAO and warm ENSO events for ozone variability.

In agreement with earlier work we find significant negative trends in column ozone over the USA in 1970-1995 (the period with almost linearly increasing ODSs). Although column ozone values over the USA ceased to decrease around the turn of the century, the observational records for 19962010 generally show positive, but insignificant, trends and thus do not yet show a clear signature of the onset of ozone recovery. Trends derived excluding extremes from the records are much smaller than those derived from the full records, consistent with previous results for other regions and data sets. The contribution of low- and high-ozone events to winter and spring mean column ozone is bounded by about $\pm 5 \%$, a value roughly comparable to the mean negative trends in 1970-1995 (and larger than trends in individual sub-periods), indicating the importance of dynamics to ozone variability and trends.

Pattern correlations of the contribution of low- and highozone events to seasonal mean column ozone are highest for neighboring sites (i.e., Bismarck-Boulder and NashvilleWallops Island), though not homogenous among sites (e.g., seasonally dependent and time varying among individual sites). Trends for individual sub-periods (i.e., 1970-1995 and 1996-2010 (Table 2); 1970-2000 and 1990-2010; see Supplement) are mostly of the same sign at all sites but differ in magnitude and significance among seasons and time periods analyzed. 
The results presented here highlight the importance of a continued spatially distributed long-term ozone monitoring program to address future ozone changes and to detect and confirm the onset and progress of ozone recovery in the context of the Montreal Protocol.

\section{The Supplement related to this article is available online at doi:10.5194/acp-15-1585-2015-supplement.}

Acknowledgements. The authors wish to express their appreciation to the NOAA Weather Service personnel, whose efforts in making the Dobson ozone measurements over more than half a century allowed us to study some of the longest atmospheric constituent time series in existence. The authors thank the NOAA Climate Prediction Center and NCAR/UCAR climate data center for providing ENSO and NAO indices used in this study via their respective data portals. The authors are grateful to the two anonymous referees for helpful comments during the discussion phase of this paper.

The total ozone data were obtained from the World Ozone and Ultraviolet Radiation Data Centre (WOUDC) operated by Environment Canada, Toronto, Ontario, Canada, under the auspices of the World Meteorological Organization. Data files can be found on the WOUDC ftp server, ftp://ftp.tor.ec.gc.ca/pub/woudc/ Archive-NewFormat/TotalOzone_1.0_1/.

Edited by: M. Dameris

\section{References}

Alexander, M. J., Tsuda, T., and Vincent, R. A.: Latitudinal variations observed in gravity waves with short vertical wavelengths, J. Atmos. Sci., 59, 1394-1404, 2002.

Appenzeller, C., Weiss, A. K., and Staehelin, J.: North Atlantic oscillation modulates total ozone winter trends, Geophys. Res. Lett., 27, 1131-1134, 2000.

Bais, A. F., Tourpali, K., Kazantzidis, A., Akiyoshi, H., Bekki, S., Braesicke, P., Chipperfield, M. P., Dameris, M., Eyring, V., Garny, H., Iachetti, D., Jöckel, P., Kubin, A., Langematz, U., Mancini, E., Michou, M., Morgenstern, O., Nakamura, T., Newman, P. A., Pitari, G., Plummer, D. A., Rozanov, E., Shepherd, T. G., Shibata, K., Tian, W., and Yamashita, Y.: Projections of UV radiation changes in the 21 st century: impact of ozone recovery and cloud effects, Atmos. Chem. Phys., 11, 7533-7545, doi:10.5194/acp-11-7533-2011, 2011.

Brönnimann, S., Luterbacher, J., Staehelin, J., Svendby, T. M., Hansen, G., and Svenoe, T.: Extreme climate of the global troposphere and stratosphere in 1940-42 related to El Niño, Nature, 431, 971-974, doi:10.1038/nature02982, 2004.

Castanheira, J. M., Peevey, T. R., Marques, C. A. F., and Olsen, M. A.: Relationships between Brewer-Dobson circulation, double tropopauses, ozone and stratospheric water vapour, Atmos. Chem. Phys., 12, 10195-10208, doi:10.5194/acp-12-101952012, 2012.

Chandra, S., Varotsos, C., and Flynn, L. E.: The mid-latitude total ozone trends in the Northern Hemisphere, Geophys. Res. Lett., 23, 555-558, 1996.
Cleveland, R. B., Cleveland, W. S., McRae J. A., and Terpenning I.: STL: A Seasonal-Trend Decomposition Procedure Based on Loess, Journal of Official Statistics, 6, 3-73, 1990.

Davison, A. C. and Smith, R. L.: Models for exceedances over high thresholds (with Discussion), J. Roy. Stat. Soc. B., 52, 393-442, 1990.

Dobson, G. M. B.: Observers' handbook for the ozone spectrophotometer, Ann. Int. Geophys. Year, 5, 46-89, 1957.

Dobson, G. M. B.: 40 Years Research on Atmospheric Ozone at Oxford - a History, Appl. Optics, 7, 387-405, doi:10.1364/Ao.7.000387, 1968.

Fitzka, M., Hadzimustafic, J., and Simic, S.: Total ozone and Umkehr observations at Hoher Sonnblick 1994-2011: Climatology and extreme events, J. Geophys. Res., 119, 739-752, doi:10.1002/2013JD021173, 2014.

Frossard, L., Rieder, H. E., Ribatet, M., Staehelin, J., Maeder, J. A., Di Rocco, S., Davison, A. C., and Peter, T.: On the relationship between total ozone and atmospheric dynamics and chemistry at mid-latitudes - Part 1: Statistical models and spatial fingerprints of atmospheric dynamics and chemistry, Atmos. Chem. Phys., 13, 147-164, doi:10.5194/acp-13-147-2013, 2013.

Gabriel, A., Körnich, H., Lossow, S., Peters, D. H. W., Urban, J., and Murtagh, D.: Zonal asymmetries in middle atmospheric ozone and water vapour derived from Odin satellite data 20012010, Atmos. Chem. Phys., 11, 9865-9885, doi:10.5194/acp-119865-2011, 2011.

Harris, N. R. P., Kyrö, E., Staehelin, J., Brunner, D., Andersen, S.B., Godin-Beekmann, S., Dhomse, S., Hadjinicolaou, P., Hansen, G., Isaksen, I., Jrrar, A., Karpetchko, A., Kivi, R., Knudsen, B., Krizan, P., Lastovicka, J., Maeder, J., Orsolini, Y., Pyle, J. A., Rex, M., Vanicek, K., Weber, M., Wohltmann, I., Zanis, P., and Zerefos, C.: Ozone trends at northern mid- and high latitudes - a European perspective, Ann. Geophys., 26, 1207-1220, doi:10.5194/angeo-26-1207-2008, 2008.

Hegglin, M. I. and Shepherd, T. G.: Large climate-induced changes in ultraviolet index and stratosphere-to-troposphere ozone flux, Nat. Geosci., 2, 687-691, doi:10.1038/ngeo604, 2009.

Homeyer, C. R. and Bowman, K. P.: Rossby Wave Breaking and Transport between the Tropics and Extratropics above the Subtropical Jet, J. Atmos. Sci., 70, 607-626, doi:10.1175/Jas-D-120198.1, 2013.

Hood, L. L.: The solar cycle variation of total ozone: Dynamical forcing in the lower stratosphere, J. Geophys. Res.-Atmos., 102, 1355-1370, 1997.

Hood, L. L., Soukharev, B. E., and McCormack, J. P.: Decadal variability of the tropical stratosphere: Secondary influence of the El Niño-Southern Oscillation, J. Geophys. Res.-Atmos., 115, D11113, doi:10.1029/2009jd012291, 2010.

Hudson, R. D., Andrade, M. F., Follette, M. B., and Frolov, A. D.: The total ozone field separated into meteorological regimes Part 2: Northern Hemisphere mid-latitude total ozone trends, Atmos. Chem. Phys., 6, 5183-5191, doi:10.5194/acp-6-5183-2006, 2006.

Hurrell, J. W.: Decadal trends in the North-Atlantic Oscillation Regional temperatures and precipitation, Science, 269, 676-679, 1995.

Jaeger, H. and Wege, K.: Stratospheric ozone depletion at northern mid-latitudes after major volcanic eruptions, J. Atmos. Chem., 10, 273-287, 1990. 
Koch, G., Wernli, H., Schwierz, C., Staehelin, J., and Peter, T.: A composite study on the structure and formation of ozone miniholes and minihighs over central Europe, Geophys. Res. Lett., 32, L12810, doi:10.1029/2004g1022062, 2005.

Lau, N. C.: Variability of the observed midlatitude storm tracks in relation to low-frequency changes in the circulation pattern, J. Atmos. Sci., 45, 2718-2743, 1988.

Mäder, J. A., Staehelin, J., Brunner, D., Stahel, W. A., Wohltmann, I., and Peter, T.: Statistical modeling of total ozone: Selection of appropriate explanatory variables, J. Geophys. Res.-Atmos., 112, D11108, doi:10.1029/2006jd007694, 2007.

Manney, G. L., Santee, M. L., Rex, M., Livesey, N. J., Pitts, M. C., Veefkind, P., Nash, E. R., Wohltmann, I., Lehmann, R., Froidevaux, L., Poole, L. R., Schoeberl, M. R., Haffner, D. P., Davies, J., Dorokhov, V., Gernandt, H., Johnson, B., Kivi, R., Kyro, E., Larsen, N., Levelt, P. F., Makshtas, A., McElroy, C. T., Nakajima, H., Parrondo, M. C., Tarasick, D. W., von der Gathen, P., Walker, K. A., and Zinoviev, N. S.: Unprecedented Arctic ozone loss in 2011, Nature, 478, 469-475, doi:10.1038/nature10556, 2011.

Manney, G. L., Hegglin, M. I., Daffer, W. H., Schwartz, M. J., and Santee, M. L.: Climatology of Upper Tropospheric-Lower Stratospheric (UTLS) Jets and Tropopauses in MERRA, J. Climate, 27, 3248-3271, doi:10.1175/JCLI-D-13-00243.1, 2014.

Mateos, D., Antón, M., Sáenz, G., Bañón, M., Vilaplana, J. M., and García, J. A.: Dynamical and temporal characterization of the total ozone column over Spain, Clim. Dynam., 1-10, doi:10.1007/s00382-014-2223-4, 2014.

McKenzie, R. L., Aucamp, P. J., Bais, A. F., Bjorn, L. O., Ilyas, M., and Madronich, S.: Ozone depletion and climate change: impacts on UV radiation, Photoch. Photobio. Sci., 10, 182-198, doi:10.1039/C0pp90034f, 2011.

Orsolini, Y. J. and Limpasuvan, V.: The North Atlantic Oscillation and the occurrences of ozone miniholes, Geophys. Res. Lett., 28, 4099-4102, 2001.

Orsolini, Y. J. and Doblas-Reyes, F. J.: Ozone signatures of climate patterns over the Euro-Atlantic sector in the spring, Q. J. Roy. Meteor. Soc., 129, 3251-3263, doi:10.1256/qj.02.165, 2003.

Pan, L. L., Randel, W. J., Gille, J. C., Hall, W. D., Nardi, B., Massie, S., Yudin, V., Khosravi, R., Konopka, P., and Tarasick, D.: Tropospheric intrusions associated with the secondary tropopause, J. Geophys. Res.-Atmos., 114, D10302, doi:10.1029/2008jd011374, 2009.

Ribatet, M., Ouarda, T., Sauquet, E., and Gresillon, J. M.: Modeling all exceedances above a threshold using an extremal dependence structure: Inferences on several flood characteristics, Water Resour. Res., 45, W03407, doi:10.1029/2007wr006322, 2009.

Rieder, H. E., Staehelin, J., Maeder, J. A., Peter, T., Ribatet, M., Davison, A. C., Stübi, R., Weihs, P., and Holawe, F.: Extreme events in total ozone over Arosa - Part 2: Fingerprints of atmospheric dynamics and chemistry and effects on mean values and long-term changes, Atmos. Chem. Phys., 10, 10033-10045, doi:10.5194/acp-10-10033-2010, 2010a.

Rieder, H. E., Staehelin, J., Maeder, J. A., Peter, T., Ribatet, M., Davison, A. C., Stübi, R., Weihs, P., and Holawe, F.: Extreme events in total ozone over Arosa - Part 1: Application of extreme value theory, Atmos. Chem. Phys., 10, 10021-10031, doi:10.5194/acp-10-10021-2010, 2010b.

Rieder, H. E., Jancso, L. M., Di Rocco, S., Staehelin, J., Maeder, J. A., Peter, T., Ribatet, M., Davison, A. C., De Backer, H., Koehler,
U., Krzyscin, J., and Vanicek, K.: Extreme events in total ozone over the Northern mid-latitudes: an analysis based on long-term data sets from five European ground-based stations, Tellus B., 63, 860-874, doi:10.1111/j.1600-0889.2011.00575.x, 2011.

Rieder, H. E., Frossard, L., Ribatet, M., Staehelin, J., Maeder, J. A., Di Rocco, S., Davison, A. C., Peter, T., Weihs, P., and Holawe, F.: On the relationship between total ozone and atmospheric dynamics and chemistry at mid-latitudes - Part 2: The effects of the El Niño/Southern Oscillation, volcanic eruptions and contributions of atmospheric dynamics and chemistry to long-term total ozone changes, Atmos. Chem. Phys., 13, 165-179, doi:10.5194/acp-13165-2013, 2013.

Rigby, M., Prinn, R. G., O’Doherty, S., Montzka, S. A., McCulloch, A., Harth, C. M., Mühle, J., Salameh, P. K., Weiss, R. F., Young, D., Simmonds, P. G., Hall, B. D., Dutton, G. S., Nance, D., Mondeel, D. J., Elkins, J. W., Krummel, P. B., Steele, L. P., and Fraser, P. J.: Re-evaluation of the lifetimes of the major CFCs and $\mathrm{CH}_{3} \mathrm{CCl} 3$ using atmospheric trends, Atmos. Chem. Phys., 13, 2691-2702, doi:10.5194/acp-13-2691-2013, 2013.

Robock, A.: Volcanic eruptions and climate, Rev. Geophys., 38, 191-219, 2000.

Schnadt Poberaj, C., Staehelin, J., and Brunner, D.: Missing stratospheric ozone decrease at Southern Hemisphere middle latitudes after Mt. Pinatubo: A dynamical perspective, J. Atmos. Sci., 68, 1922-1945, 2011.

Schwartz, M. J., Manney, G. L., Hegglin, M. I., Liversey, N. J., Santee, M. L., and Daffer, W. H.: Climatology and variability of trace gases in extratropical double-tropopause regions from MLS, HIRDLS and ACE-FTS measurements, J. Geophys. Res.Atmos., 2015.

Seidel, D. J., Fu, Q., Randel, W. J., and Reichler, T. J.: Widening of the tropical belt in a changing climate, Nat. Geosci., 1, 21-24, doi:10.1038/ngeo.2007.38, 2008.

Shepherd, T. G.: Dynamics, stratospheric ozone, and climate change, Atmos. Ocean, 46, 117-138, doi:10.3137/ao.460106, 2008.

Solomon, S.: Stratospheric ozone depletion: A review of concepts and history, Rev. Geophys., 37, 275-316, 1999.

Steinbrecht, W., Claude, H., Kohler, U., and Hoinka, K. P.: Correlations between tropopause height and total ozone: Implications for long-term changes, J. Geophys. Res.-Atmos., 103, 1918319192, 1998.

Thompson, D. W. J. and Wallace, J. M.: Annular modes in the extratropical circulation. Part I: Month-to-month variability, J. Climate, 13, 1000-1016, 2000.

Tourpali, K., Bais, A. F., Kazantzidis, A., Zerefos, C. S., Akiyoshi, H., Austin, J., Brühl, C., Butchart, N., Chipperfield, M. P., Dameris, M., Deushi, M., Eyring, V., Giorgetta, M. A., Kinnison, D. E., Mancini, E., Marsh, D. R., Nagashima, T., Pitari, G., Plummer, D. A., Rozanov, E., Shibata, K., and Tian, W.: Clear sky UV simulations for the 21 st century based on ozone and temperature projections from Chemistry-Climate Models, Atmos. Chem. Phys., 9, 1165-1172, doi:10.5194/acp-9-1165-2009, 2009.

Trenberth, K. E.: Progress during TOGA in understanding and modeling global teleconnections associated with tropical sea surface temperatures, J. Geophys. Res., 103, 14291-14324, 1998.

WMO: Scientific Assessment of Ozone Depletion: 2006, Global Ozone Research and Monitoring Project, 50, 572, 2007. 
WMO: Scientific Assessment of Ozone Depletion: 2010, Global Ozone Research and Monitoring Project 50, 516, 2011.

Wohltmann, I., Lehmann, R., Rex, M., Brunner, D., and Mader, J. A.: A process-oriented regression model for column ozone, J. Geophys. Res.-Atmos., 112, D12304, doi:10.1029/2006jd007573, 2007.
Ziemke, J. R., Chandra, S., Oman, L. D., and Bhartia, P. K.: A new ENSO index derived from satellite measurements of column ozone, Atmos. Chem. Phys., 10, 3711-3721, doi:10.5194/acp10-3711-2010, 2010. 